\title{
\begin{tabular}{l|l} 
Mibraries & DSpace@MIT
\end{tabular}
}

\author{
MIT Open Access Articles
}

Challenges to Understanding the Dynamic Response of Greenland's Marine Terminating Glaciers to Oceanic and Atmospheric Forcing

The MIT Faculty has made this article openly available. Please share how this access benefits you. Your story matters.

Citation: Straneo, Fiammetta, Patrick Heimbach, Olga Sergienko, Gordon Hamilton, Ginny Catania, Stephen Griffies, Robert Hallberg, et al. "Challenges to Understanding the Dynamic Response of Greenland's Marine Terminating Glaciers to Oceanic and Atmospheric Forcing." Bull. Amer. Meteor. Soc. 94, no. 8 (August 2013): 1131-1144. (C) 2013 American Meteorological Society

As Published: http://dx.doi.org/10.1175/bams-d-12-00100.1

Publisher: American Meteorological Society

Persistent URL: http://hdl.handle.net/1721.1/87785

Version: Final published version: final published article, as it appeared in a journal, conference proceedings, or other formally published context

Terms of Use: Article is made available in accordance with the publisher's policy and may be subject to US copyright law. Please refer to the publisher's site for terms of use. 


\section{CHALLENGES TO UNDERSTANDING THE DYNAMIC RESPONSE OF GREENLAND'S MARINE TERMINATING GLACIERS TO OCEANIC AND ATMOSPHERIC FORCING}

by Fiammetta Straneo, Patrick Heimbach, Olga Sergienko, Gordon Hamilton, Ginny Catania, Stephen Griffies, Robert Hallberg, Adrian Jenkins, Ian Joughin, Roman Motyka, W. Tad Pfeffer, Stephen F. Price, Eric Rignot, Ted Scambos, Martin Truffer, and Andreas Vieli

An interdisciplinary and multifaceted approach is needed to understand the forcings and mechanisms behind the recent retreat and acceleration of Greenland's glaciers and its implications for future sea level rise

M ass loss from the Greenland and Antarctic ice sheets tripled over the last two decades, from $100 \pm 92 \mathrm{Gt} \mathrm{yr}^{-1}\left(0.28 \pm 0.26 \mathrm{~mm} \mathrm{yr}^{-1}\right.$ sea level equivalent) during 1992-2000 to $298 \pm 58 \mathrm{Gt} \mathrm{yr}^{-1}$ $\left(0.83 \pm 0.16 \mathrm{~mm} \mathrm{yr}^{-1}\right)$ during 2000-11 [see Shepherd et al. (2012) and references therein]. It presently accounts for about one-quarter of the observed global sea level rise (SLR) from 1992 to 2008 of 3.4 $\pm 0.4 \mathrm{~mm} \mathrm{yr}^{-1}$ (Cazenave and Llovel 2010; Church and White 2011). This increase is largely due to
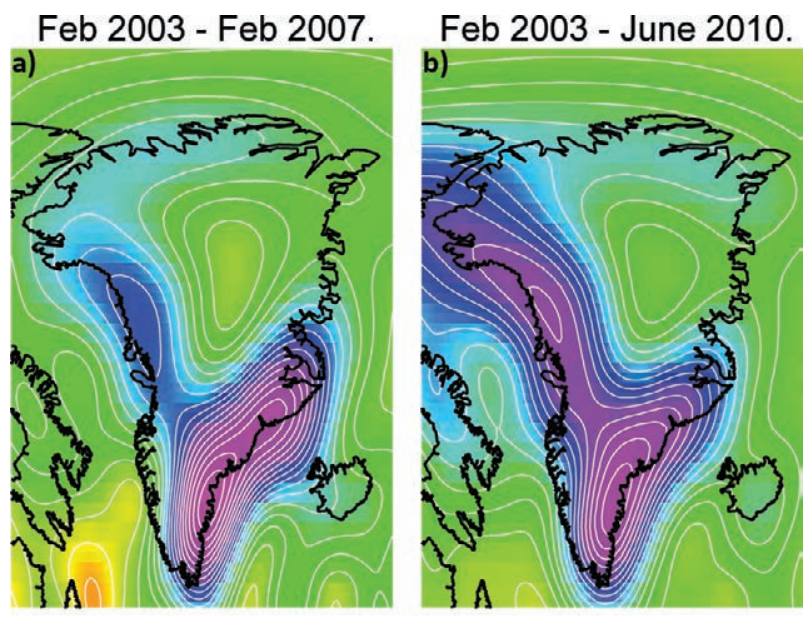

\footnotetext{
$\begin{array}{llllllllllllllllll}-16 & -9 & -8 & -7 & -6 & -5 & -4 & -3 & -2 & -1 & 0 & 1 & 2 & 3 & 4 & 5\end{array}$ $\mathrm{cm} / \mathrm{yr}$ water thickness equivalent
}

Greenland, whose loss rose from $51 \pm 65 \mathrm{Gt} \mathrm{yr}^{-1}$ (1992-2000) to $211 \pm 37 \mathrm{Gt} \mathrm{yr}^{-1}$ (2000-11) (Shepherd et al. 2012). Independent geodetic measurements of continental uplift and Earth rotation support these changes (e.g., Jiang et al. 2010; Nerem and Wahr 2011; Bevis et al. 2012). Greenland's loss, in turn, is approximately equally partitioned between increased surface melting due to rising air temperatures (Cappelen 2010) and the unpredicted, surprising, and rapid speedup, retreat, and thinning of glaciers (Howat et al. 2007; Luckman et al. 2006; van den Broeke et al. 2009). Even though the precise chain of events is still debated, the widespread and nearsynchronous glacier retreat and its coincidence with a period of oceanic and atmospheric warming suggest a common climate driver. A growing body of evidence points to the marine margins of these glaciers as the region from which this dynamic response originated (Figs. 1 and 2), leading to the hypothesis that the recent dynamic mass loss from the Greenland Ice Sheet

Fig. I. Recent mass loss from Greenland is concentrated along the coastal margins of southern Greenland and spreading along western Greenland. Rate of mass loss (in centimeters per year water equivalent thickness) from Gravity Recovery and Climate Experiment (GRACE) measurements (a) between Feb 2003 and Feb 2007 and (b) between Feb 2003 and Feb 2010 [redrawn and extended from Khan et al. (2010); courtesy of S. A. Khan, DTU, Denmark]. 
(GrIS) was triggered by perturbations at the ice front of outlet glaciers, where it is in contact with ocean waters.

While a similar scenario is invoked to explain recent changes in Antarctica (Joughin and Alley 2011; Joughin et al. 2012), Greenland warrants special attention. First, it is not evident that Antarcticderived results can be applied to Greenland's marineterminating glaciers, given the different coastal and climatic conditions at the two poles, and the different types of ice flow behavior encountered (Truffer and Echelmeyer 2003). Second, the proximity of Greenland to the North Atlantic's dense water formation regions (in particular, the Greenland, Irminger, and Labrador Seas) implies that an increasing discharge of freshwater from Greenland (Bamber et al. 2012) could potentially impact the large-scale overturning circulation of the North Atlantic with possible far-reaching consequences for global heat transport and climate [see among the early studies Manabe and Stouffer (1988), and most recently Weijer et al. (2012), and references therein].

The significance of the dynamic response has been appreciated only recently and was not captured by the previous generation of ice sheet models (Little et al. 2007). Indeed, in the 2007 Intergovernmental Panel on Climate Change Fourth Assessment Report

AFFILIATIONS: StRANEO-Woods Hole Oceanographic Institution, Woods Hole, Massachusetts; HeIMBACHMassachusetts Institute of Technology, Cambridge, Massachusetts; SeRGIENKO-Princeton University, and NOAA/Geophysical Fluid Dynamics Laboratory, Princeton, New Jersey; HaMILTONUniversity of Maine, Orono, Maine; CATANIA-The University of Texas at Austin, Austin, Texas; Griffies and Hallberg-NOAA/ Geophysical Fluid Dynamics Laboratory, Princeton, New Jersey; JENKINS-British Antarctic Survey, Cambridge, United Kingdom; JOUGHIN-University of Washington, Seattle, Washington; MOTYKA AND TrufFer-University of Alaska Fairbanks, Fairbanks, Alaska; Pfeffer-University of Colorado, Boulder, Colorado; PrICELos Alamos National Laboratory, Los Alamos, New Mexico; RIGNOT-University of California, Irvine, Irvine, California, and Jet Propulsion Laboratory, Pasadena, California; ScAmBos-National Snow and Ice Data Center, University of Colorado, Boulder, Colorado; VIELI—Durham University, Durham, United Kingdom CORRESPONDING AUTHOR: Fiammetta Straneo, Mail Stop 21, WHOI, 266 Woods Hole Road, Woods Hole, MA 02543-1050 E-mail: fstraneo@whoi.edu

The abstract for this article can be found in this issue, following the table of contents.

DOI:10.1175/BAMS-D-12-00100.1

In final form 12 December 2012

(C)2013 American Meteorological Society
(AR4), this shortcoming was identified as the largest source of uncertainty in SLR projections (Lemke et al. 2007). The global-scale problem was described in a National Science Foundation (NSF) report on "A Research Program for Projecting Sea Level Rise from Land Ice Loss" (Bindschadler et al. 2011). New-generation ice sheet models contain significant improvements that allow for more realistic simulation of outlet glaciers and their future evolution (e.g., Favier et al. 2012; Larour et al. 2012; Seddik et al. 2012). However, understanding of the relevant climate forcings and interaction with other components of the climate system has not yet reached the level necessary for realistic coupling of ice sheet models to global climate models. As a result, projections of SLR from Greenland by 2100 vary from 0.01 to $0.54 \mathrm{~m}$ (Meier et al. 2007; Rahmstorf 2007; Pfeffer et al. 2008; Vermeer and Rahmstorf 2009; Price et al. 2011). Overcoming this problem will require the inclusion of the forcings and mechanisms driving the dynamic responses of ice sheets in global climate models, either explicitly or in parameterized form. This becomes a priority in light of the predicted large changes in the atmosphere and ocean around Greenland. For example, using 19 Coupled Model Intercomparison Project, phase 3 (CMIP3)/AR4 climate models, Yin et al. (2011) estimate a warming of $1.7^{\circ}-2^{\circ} \mathrm{C}$ of the upper ocean around Greenland by 2100 , almost twice the global mean. More concern follows from the fact that several of Greenland's large outlet glaciers and ice streams, such as the "North-East Greenland Ice Stream" or Jakobshavn Isbræ, lie in submarine troughs that extend tens of kilometers into the ice sheet interior (Allen 2010). Destabilization of these outlet glaciers could lead to rapid and large mass losses (Hughes 1986), a scenario currently under debate (e.g, Joughin et al. 2012).

Under the sponsorship of U.S. Climate Variability and Predictability (CLIVAR), a working group on Greenland Ice Sheet-Ocean Interactions (GRISO), composed of representatives from the multiple disciplines involved, was established in January 2011 to develop strategies to address dynamic response of Greenland's glaciers to climate forcing (U.S. CLIVAR Project Office 2012b). This paper, led by this group but including the input of a broader group of interested scientists, summarizes the state of knowledge, identifies the most pressing issues, and makes recommendations on how to move forward collectively.

OBSERVATIONS, MECHANISMS, AND FORCINGS. Evidence from observations. Approximately half of the GrIS increased mass loss over the 

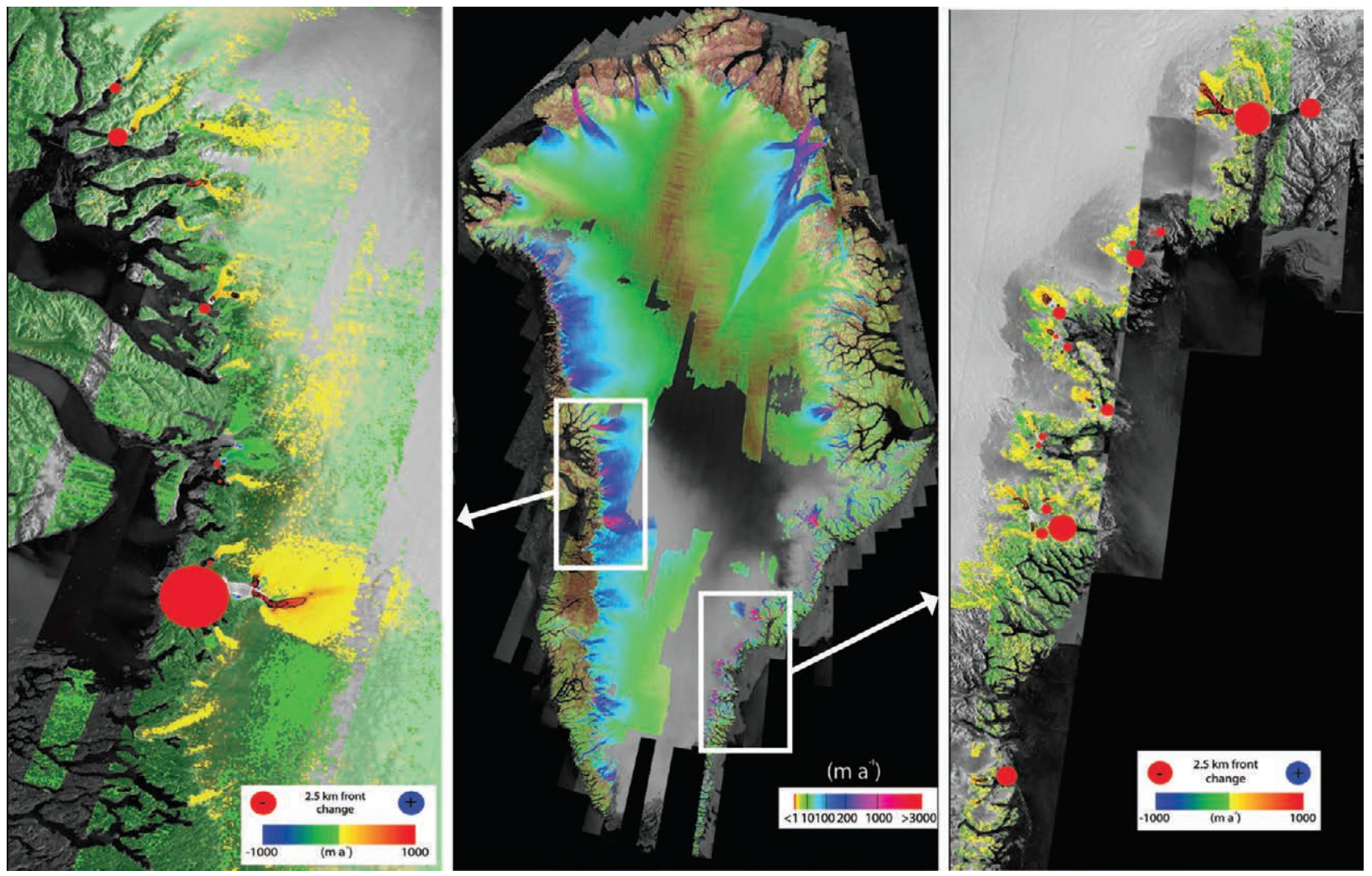

FIG. 2. (middle) Surface flow speed (in meters per annum, i.e., meters per year) showing how Greenland's fast-flowing outlet glaciers terminate into long, narrow fjords. Speedup (colors) and terminus retreat (circles) of outlet glaciers between 2000-0I and 2005-06 in (left) western and (right) southeastern Greenland (from Joughin et al. 2010).

last decade is attributed to the speedup and retreat of outlet glaciers in western and southeastern Greenland (Luckman et al. 2006; Howat et al. 2007; Stearns and Hamilton 2007; van den Broeke et al. 2009; Howat et al. 2011). These are marine-terminating or "tidewater" glaciers discharging into long, narrow, and deep fjords (Sole et al. 2008; Moon et al. 2012), such as Helheim (Fig. 3) and Kangerdlugssuaq glaciers, and Jakobshavn Isbræ. They are characterized by relatively short, floating ice tongues or grounded termini (Fig. 4a). Their mass balance is largely controlled by seasonal calving, which contributes to the presence of an ice mélange, a mixture of sea ice and icebergs, in front of the glacier termini (Amundson et al. 2010). For such glaciers, ice flow at the front, as well as the circulation of ocean waters and of the mélange, is strongly constrained by the fjord setting (e.g., MacAyeal et al. 2012). Since their speedup in the early 2000s, some glaciers have subsequently slowed down (although not necessarily to their preacceleration velocity), while others have continued in their state of accelerated flow (Howat et al. 2011; Joughin et al. 2012). In general, the spatial and temporal variability of the glaciers' speedups are complex, reflecting in- fluence from a combination of forcings (Moon et al. 2012). Likely these combined forcings also explain why some glaciers adjacent to the glaciers that have sped up have maintained constant flow rates.

Similarly, no clear trend toward increasing speed is found for Greenland's northern glaciers (Moon et al. 2012), some of which are characterized by long floating ice tongues (10-90 km; Fig. 4b), for example, Petermann Glacier (Rignot and Steffen, 2008) and Nioghalvfjerdsbrae/79 North Glacier (Mayer et al. 2000; Joughin et al. 2001). These glaciers still calve, but, unlike the glaciers discussed above, their mass balance is largely controlled by surface and submarine melting, and their calving is likely influenced by quasi-permanent sea ice (Reeh et al. 2001). Petermann Glacier, in particular, lost about $25 \%$ of its tongue in August 2010 and another break-up of about half this size occurred in July 2012. Whether these triggered a dynamic response upstream is subject to ongoing research (Falkner et al. 2011; Nick et al. 2012).

The synchronous nature of glacier speedups and their clustering in the western and southeastern sectors of Greenland (Figs. 1 and 2; Howat et al. 2007; Rignot and Kanagaratnam 2006) suggest that glaciers 

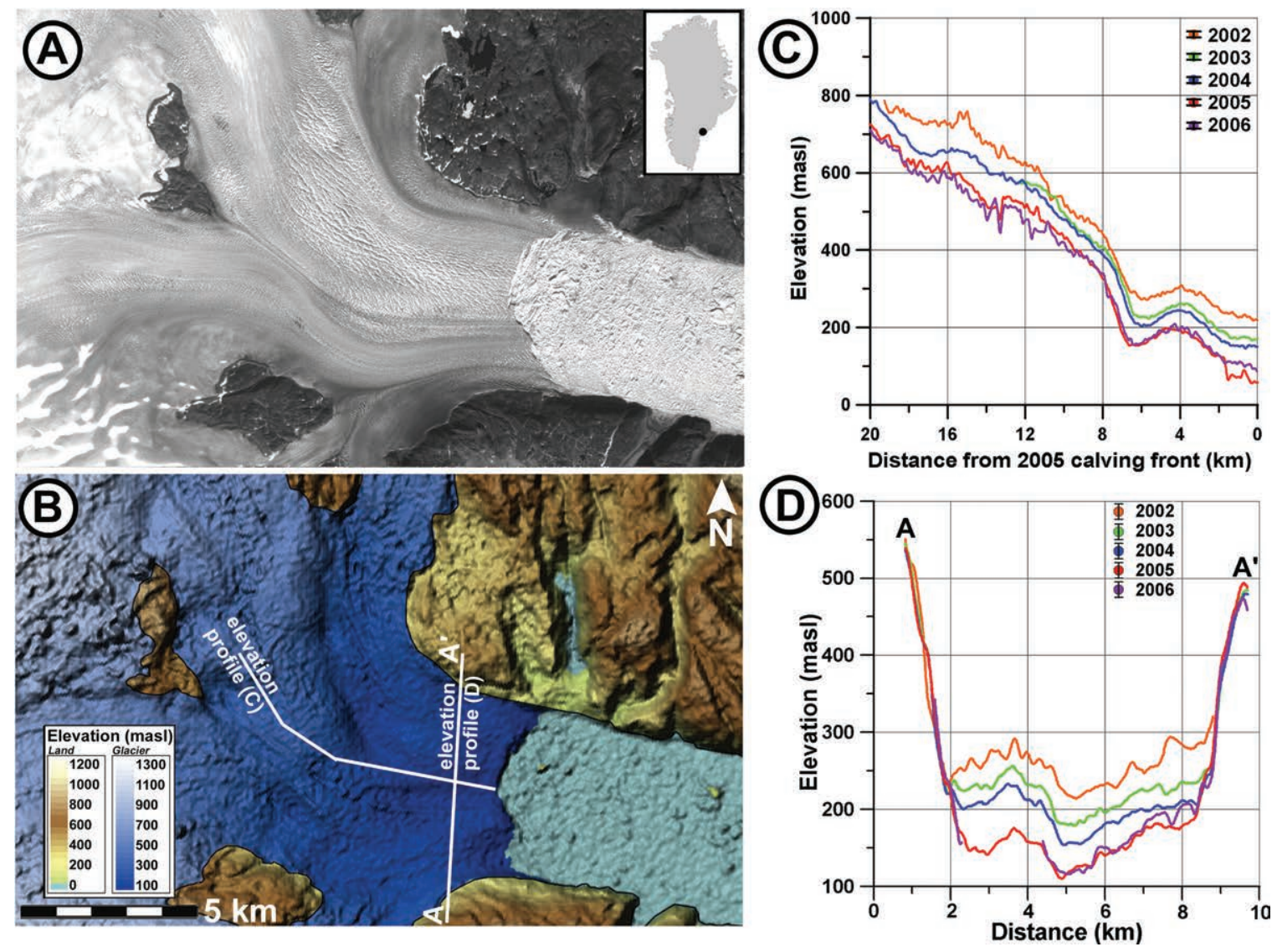

FIG. 3. Retreat and thinning of a large Greenland tidewater glacier, Helheim Glacier, in southeastern Greenland. (a) Advanced Spaceborne Thermal Emission and Reflection (ASTER) image acquired 29 Aug 2005. (b) Surface topography derived from (a). (c) Surface elevation change on the along-flow elevation profile labeled in (a) (0 km is the terminus). (d) Surface elevation change on the across-flow elevation profile labeled in (a) (from Stearns and Hamilton 2007).

are responding to a common climate forcing (Vieli and Nick 2011; Moon et al. 2012). The precise chain of events is not fully resolved, but recent work indicates that increases in speed began at the marine termini (Pfeffer 2007; Sole et al. 2008; Price et al. 2008, 2011; Pritchard et al. 2009; Nick et al. 2009) and followed a mostly similar sequence of events. Initial retreat of the marine terminus led to decreased resistance to flow, and resulted in speedup, rapid surface thinning, increased calving, and, possibly, amplification due to positive ice dynamics feedbacks (Joughin et al. 2004; Thomas 2004; Price et al. 2008; Vieli and Nick 2011; Joughin et al. 2012). Hence, the relevant climatic forcings (atmospheric, oceanic, or both) are those responsible for the initial glacier retreat.

Oceanic and atmospheric forcing of Greenland's glaciers. Greenland's large outlet glaciers terminate in fjords, which are typically less than $10 \mathrm{~km}$ wide, tens of kilometers long, and hundreds to 1,000 $\mathrm{m}$ deep. These fjords connect the ice sheet margins to Greenland's continental shelf, where cold, fresh Arctic waters flow alongside of or above warm, salty Atlantic waters (Fig. 5). Recent surveys have shown that both water masses are present in the fjords and that the warmest Atlantic waters $\left(\sim 2^{\circ}-5^{\circ} \mathrm{C}\right)$ are found in fjords in southeastern and western Greenland at the margins of the North Atlantic's subpolar gyre [see Straneo et al. (2012), and references therein]. Deep troughs stretching across the continental shelf (e.g., Sutherland and Pickart 2008) and fjord sills that are deeper than the Atlantic-Arctic water interface contribute to the inflow of Atlantic waters into the fjords (e.g., Straneo et al. 2010; Johnson et al. 2011; Christoffersen et al. 2011), but the mechanisms controlling this exchange are largely unknown.

The bulk of the glaciers that accelerated during the last decade are located at the margins of the North Atlantic's subpolar gyre and its extension into Baffin Bay in southeastern and western Greenland. The waters in the subpolar gyre began to warm roughly at the same time as the glaciers started to retreat (Bersch et al. 
Fig. 4. Schematic of (a) tidewater and (b) floating ice tongue glacier. Proposed mechanisms for glacier retreat and ensuing glacier acceleration are shown in red (see "Overview of proposed hypotheses and mechanisms"). Key processes that need to be addressed are identified in blue (see "Process studies targeting specific dynamic regimes").

2007; Zweng and Munchow 2006), leading investigators to suggest that the glacier retreat was driven by oceanic warming (Holland et al. 2008; Murray et al. 2010; Motyka et al. 2011). Yet the mechanisms linking ocean warming with glacier retreat remain largely speculative because of a lack of long-term records from the glaciers and the fjords and a limited understanding of the dynamics involved. Some support for the oceandriven hypothesis, however, is found in recent paleoreconstructions. Lloyd et al. (2011) have linked changes in the terminus position of Jakobshavn Isbræ over the last $\sim 100$ years to changes in water temperatures on the western Greenland shelf as reconstructed from paleoproxies. Andresen et al. (2012) linked calving activity of Helheim Glacier over the last 120 years (reconstructed using sediment cores) to variations in several oceanic and atmospheric indices, including a proxy for ocean water properties on Greenland's southeastern shelf.

If glacier retreat was due to oceanic warming, then we may expect the changes
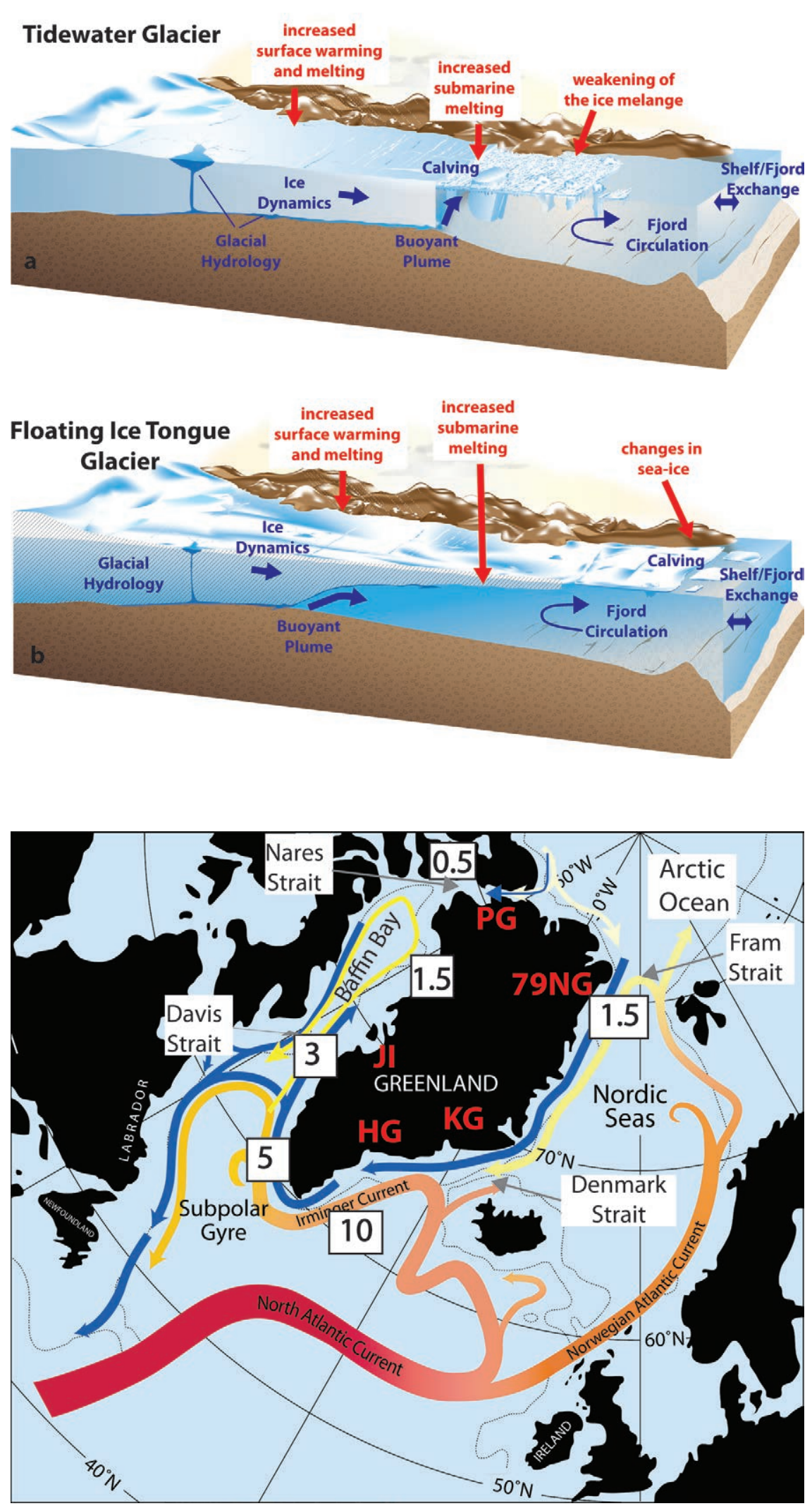

FIG. 5. Schematic circulation of warm Atlantic (red to yellow) and cold Arctic (blue) water masses around Greenland. Numbers indicate the mean temperature $\left({ }^{\circ} \mathrm{C}\right)$ of the Atlantic water on the continental shelf (from Straneo et al. 2012). 
to continue, since climate models predict that the ocean region around southern Greenland will experience a pronounced ocean warming (Yin et al. 2011). Furthermore, if oceanic variability can trigger glacier retreat, then it is unlikely that changes in Greenland will be confined to one region. Indeed, recent data (e.g., Schauer et al. 2008; Polyakov et al. 2004) indicate warming of the waters in the Nordic seas and Arctic Ocean, raising the question of whether the glaciers in northeastern and northern Greenland may soon start to retreat. The extent to which these glaciers, many of which are fairly slow moving with land-terminating or slowly calving termini (Moon et al. 2012), are susceptible to warming remains to be established.

Summer surface melt occurs around the marine margins of the GrIS and extends far inland in southern and western Greenland. Melting has increased (and spread farther) in the last decade according to both satellite-based observations and models (Hall et al. 2008; van den Broeke et al. 2009), thus generating larger amounts of surface and subglacial discharge that is funneled toward the tidewater glaciers and discharged in the fjords. The increase in surface melt is attributed both to rising air temperatures over Greenland (Cappelen 2010) and to a decrease in the surface albedo triggered by increased melting (Tedesco et al. 2011; Fettweis et al. 2011). Warming air temperatures over Greenland, in turn, have been linked to anomalous advection of warm air due to changes in the subpolar jet stream (Hanna et al. 2009). Another important atmospheric forcing of Greenland's tidewater glaciers is the strong wind events generated by the interaction of the large-scale atmospheric circulation (and the jet stream, in particular) with Greenland's steep orography_including barrier winds, katabatic winds, tip jets, etc. (e.g., Klein and Heinemann 2002; Moore and Renfrew 2005; Davini et al. 2012).

Overview of proposed hypotheses and mechanisms. The leading hypotheses proposed to explain the initial glacier retreat may be grouped into three broad types of trigger mechanisms (see also Vieli and Nick 2011):

1) increased submarine melting at the ice-ocean interface,

2) reduction or weakening of the ice mélange,

3) increased crevassing and structural weakening of the glacier from surface warming and melt.

Understanding how these mechanisms may act to perturb the ice sheet is key to elucidating the chain of events that led to the glaciers' increased flow speed.
Below, we review these mechanisms and their links to oceanic and/or atmospheric forcings, highlighting what is and is not known.

SubMARINE MELTING AT THE ICE-OCEAN INTERFACE. Ocean waters at temperatures above freezing that come in contact with the ice front can drive submarine melting. This melting contributes to the overall glacier mass balance (e.g., it is a major mass sink for Antarctica and northern Greenland's ice shelves/ floating tongues), but it can also affect glacier stability by modifying the ice front. Thus, it is possible for increased rates of submarine melting, as a result of oceanic warming, to lead to increased calving and/ or terminus retreat (e.g., Jakobshavn Isbrae; Vieli and Nick 2011; Motyka et al. 2011; Holland et al. 2008), disintegration of the ice tongues, and glacier speedup (Joughin et al. 2004).

In Greenland, recent surveys have shown that submarine melting is primarily driven by Atlantic waters (Rignot et al. 2010; Johnson et al. 2011; Straneo et al. 2012). [The surface layers of the fjords are warm in summer, due to surface heating (Murray et al. 2010; Christoffersen et al. 2011), but it is unclear whether these waters reach the glaciers.] These surveys have also shown that the fjords contain enough heat to melt significant amounts of ice (e.g., Holland et al. 2008; Rignot et al. 2010; Johnson et al. 2011; Motyka et al. 2011; Straneo et al. 2012; Sutherland and Straneo 2012), and that melting is limited not by the available heat but by the rate of "heat delivery" to the ice. This heat delivery, in turn, depends on a range of glaciological, oceanic, and atmospheric processes and parameters that are poorly understood.

At the ice front, the exchange of heat and mass across the ice-ocean boundary occurs on scales of millimeters to centimers, which are not resolved by either field observations or models. Hence, these transfers are heavily parameterized (e.g., Hellmer and Olbers 1989; Holland and Jenkins 1999) and dependent on the velocity and temperature (and to a lesser extent salinity) in the oceanic boundary layer (Jenkins et al. 2010). Here, the flow is conceptualized as a buoyant plume, tens of meters thick, and carrying meltwater that rises along the ice-ocean interface (Jenkins 1991, 2011). Its dynamics are influenced by glaciological factors including ice geometry (including the slope of the glacier front/ ice shelf/floating tongue); ice roughness [including the impact of channels in the ice as observed at Nioghalvfjerdsfjorden/79 North (Seroussi et al. 2011), Petermann (Rignot and Steffen 2008), and Jakobshavn (Motyka et al. 2011)]; and the discharge 
of surface or basal melt through the glacier's channels (Rignot et al. 2010; Jenkins 2011; Straneo et al. 2011; $\mathrm{Xu}$ et al. 2012; Sciascia et al. 2013).

The oceanic boundary layer and the plume are also influenced by the circulation and supply of Atlantic water driven by forcings other than the glacier itself, including tides, regional winds, and shelf variability (e.g. Haine et al. 2009). Indeed, recent surveys have revealed the fjord circulation to be complex and highly variable (Sutherland and Straneo 2012; Mortensen et al. 2011). At present only a few estimates of summer submarine melting of various Greenland glaciers have been obtained from ocean measurements (e.g., Rignot et al. 2010; Johnson et al. 2011; Sutherland and Straneo 2012). They are highly uncertain, though, given the intrinsic challenges of measuring heat transport in highly variable, iceberg-choked fjords.

VARIABILITY OF THE ICE MÉLANGE OR LANDFAST SEA ICE IN FRONT OF THE GLACIER. Changes in the ice mélange and sea ice (Fig. 4a) can affect the rate of calving and the glaciers' stability (Reeh et al. 2001; Amundson et al. 2010; Walter et al. 2012). The mélange varies seasonally in extent and rigidity, which may modulate calving and speedup of outlet glaciers (Howat et al. 2010). The presence of a "solid" boundary at the water surface can dampen externally forced fjord circulation (e.g., MacAyeal et al. 2012) and reduce the surface forcing. For glaciers with long floating ice-tongues, the presence of landfast sea ice (Fig. 4b) can similarly influence calving (e.g., Reeh et al. 2001).

Both the ice mélange and the sea ice at the edge of Greenland's tidewater glaciers are susceptible to oceanic and atmospheric forcing. Weakening and potential break up of the ice can result from increased submarine melting (e.g., from warming ocean waters), increased surface melting (e.g., from rising air temperatures), or increased mechanical stresses (e.g., by an increase in the surface wind stress or surface currents).

INCREASED CREVASSING, CALVING, AND REDUCED STRUCTURAL COHERENCE DUE TO SURFACE WARMING AND INCREASED SURFACE MELT. Recent observational and modeling work suggests that enhanced lubrication at the bed from sustained increased surface melt likely does not play a major role in the retreat of fast-flowing glaciers (Joughin et al. 2008; Nick et al. 2009; Schoof 2010; Andersen et al. 2011; Bartholomew et al. 2012). In fact, delivery of additional meltwater to the bed might result in ice flow deceleration (e.g., Schoof 2010; Sundal et al. 2011; Hoffman et al. 2011). Meltwater filling of crevasses, however, might lead to mechanical and rheological weakening of ice, which, in turn, can enhance ice flow, as suggested by modeling and observations (Phillips et al. 2010; van der Veen et al. 2011; Colgan et al. 2011). In general, the connection between calving activity and climate forcings is not straightforward (Post et al. 2011). For many of Greenland's tidewater glaciers, however, glacier calving responds to seasonal forcing (Sohn et al. 1998); thus, irrespective of which processes drive calving, warming that extends summer and shortens winter should lead to greater calving rates.

A RESEARCH STRATEGY. The gap in our understanding of the mechanisms linking climate forcings, perturbations at marine glacier margins, and their dynamic responses constitutes a major obstacle to reducing uncertainties in Greenland's projected mass change. An interdisciplinary and multifaceted approach is needed, combining fieldwork, remote sensing, sustained observations, laboratory experiments, modeling, data analysis, and synthesis. It requires the development of existing systems as well as the establishment of new systems in a number of spheres:

- methodology: new approaches, theories, numerical methods to study ice-ocean coupled systems at various spatial and temporal scales;

- technology: new methods and instrumentation systems (e.g., to observe ice and seawater properties in harsh environments);

- human: close collaboration between diverse communities of scientists (oceanographers, glaciologists, sea ice and atmospheric scientists, observationalists, theoreticians, and numerical modelers) and across international borders; and

- organizational: proposal review and project coordination may unleash a leveraging effect, especially in terms of field campaign coordination. This is particularly the case at an international level, where no obvious field coordination mechanisms exist.

To move forward we propose three distinct scientific approaches: 1) process studies targeting specific dynamic regimes, 2) sustained observation of key systems in Greenland, and 3) inclusion of the dynamics into Earth system models. In addition to these approaches (described in detail below), several key parameters must be available to understand and model the relevant dynamics, including fjord and continental shelf bathymetry, subglacial topography, paleoproxy records, and well-resolved oceanic, atmospheric, and sea ice boundary conditions. 
Process studies targeting specific dynamic regimes. Studies are needed to understand the following relevant processes and to develop/improve model parameterizations.

- Ice-ocean boundary layer and plume dynamics: Key measurements and modeling of the turbulent processes and their controls are needed to estimate submarine melt rates and to develop appropriate melt-rate parameterizations. Basic questions relate to how ice roughness, ice base slope, subglacial discharge, fjord circulation, and other local forcings influence the dynamics of the buoyant plume, the turbulent mixing, the circulation, and the submarine melt rate at the ice-ocean interface.

- Fjord circulation and exchanges with the continental shelf: Integrated observational, modeling, and data analysis efforts are needed to understand how the fjord and shelf dynamics impact properties at the ice-ocean boundary, including the sea ice and/or the ice mélange. Establishing commonalities and differences in the fjord/shelf dynamics for the large ice tongues in northern Greenland compared with the rapidly calving glaciers in the south is also key to understanding all regimes of fjord/glacier systems.

- Glacial hydrology: Knowledge of glacial hydrology, including the amount and timing of discharge of surface melt into the fjord environment, is key to understanding ice flow, submarine melt rate, and plume dynamics. Efforts are needed to link local atmospheric forcing to glacial hydrology, and subsequent hydrologic processes (e.g., glacier sliding) to both the ice and water drainage regimes of an outlet glacier.

- Glacier dynamics: Process studies need to address the transition in ice flow from large catchment basins to narrow outlet glaciers, in order to understand how the changes in stress distribution and large-scale bed geometry influence the flow of ice and its supply to the terminus. High-resolution bedrock topography beneath outlet glaciers and their catchment basins are therefore crucial.

- Calving: Calving plays a crucial role in both ice loss at the terminus and (indirectly) on the acceleration of inland ice flow, but its description remains elusive. Observational, theoretical, and experimental modeling efforts are necessary to develop a full understanding and realistic parameterizations of glacier calving.

Sustained observations of key systems in Greenland. Understanding the time-evolving relationship between climate forcings, perturbations at the iceocean interface, and the responses in terms of glacier flow and mass loss requires sustained observations. Measurements should capture glacier flow; local meteorology; oceanic conditions near the glacier front, in the fjord, and on the continental shelf; and ice mélange conditions. Data collected should also provide a measure of the heat and freshwater transport into and out of key fjords to enable budget analyses and provide boundary conditions for the ocean general circulation models (GCMs).

A sustained measuring system should include both in situ as well as air- and spaceborne components. Essential variables including ice elevation, mass balance and flow speed, ocean temperaturee and salinity, and sea ice conditions should be collected on a quasi-continuous basis at a few key sites. Space- and airborne data, such as laser and radar altimetry, synthetic aperture radar (SAR) interferometry, gravimetry, ice-penetrating radar, and optical sensors, provide valuable information to constrain many of the controlling processes because of their broad spatial and temporal coverage.

An observing system sustained over decadal time scales, while ambitious, might be within reach because the majority of the drainage across the marine margins is confined to a small number ( 10) of major outlet glacier/fjord systems. The observing system may take advantage of elements already in place, including the Greenland GPS Network (GNET) constructed from 2007 onward (Bevis et al. 2012), the oceanic Arctic Observing Network (AON) and Arctic-Subarctic Ocean Fluxes (ASOF) moored arrays, and planned systems such as the Overturning in the Subpolar North Atlantic Program (OSNAP), a transbasin mooring array conceived to measure the North Atlantic subpolar gyre circulation to the east and west of southern Greenland (U.S. CLIVAR Project Office 2012a). Closer coordination of the international scientific effort already focused on Greenland outlet glaciers, fjords, and adjacent Arctic and subpolar seas; some investment in key science infrastructure (oceanographic moorings, weather stations, GPS networks, etc.); and pooling of the available logistical infrastructure would provide an essential starting point.

Complementing the sustained measurement program, a compilation and evaluation of relevant geochemistry and paleoproxy information should provide an extremely valuable context of long-term outlet glacier evolution. Mix et al. (2012) discuss the specific needs to gather new paleoproxy records and exploit existing ones. 
Synthesis of the results into Earth system models. Results of process-oriented studies and sustained observations should be integrated into large-scale circulation and Earth system models to enable improved simulations and predictions of future changes in the GrIS. Coordinated modeling efforts should focus on improving:

- Physically based parameterizations of unresolved processes. Comprehensive representation of the dynamics of Greenland outlet glaciers and fjords (at spatial resolution on the order of $100 \mathrm{~m}$ or less) is beyond the capabilities of large-scale climate models, currently operating at $50-100-\mathrm{km}$ grid spacing. Key physical processes identified and explored in the process studies need to be incorporated into global circulation and Earth system models. This will require new developments in the ice, ocean, atmosphere, and sea ice physical parameterizations and numerical methods capable to implement them in a computationally efficient manner. A close interdisciplinary collaboration has to be established to ensure progress.

- Data assimilation and parameter optimization constrained by observations. Drawing on experience from ongoing oceanographic state estimation efforts [e.g., the Estimating the Circulation and Climate of the Ocean (ECCO) project (Wunsch et al. 2009)] and in parameter inversion efforts within the ice sheet modeling community, new methodologies capable of assimilating data of diverse nature and from a variety of sources in a meaningful way are needed. State and parameter estimation requires development of comprehensive, well-structured, and sophisticated databases and data formats to allow rapid access and optimal use of the hard-won data. Maintaining and distributing these datasets will require adequate data management infrastructures, a task best taken on by experienced data centers [e.g., the National Snow and Ice Data Center (NSIDC), and the National Oceanographic Data Center (NODC)].

- Coupling of the various components of the Earth system models. Representing feedbacks between GrIS variability and the large-scale ocean/atmosphere circulation or other climate system components requires interactive coupling between ice sheet and climate models or components thereof. Ongoing coupling efforts are uncovering obstacles to be addressed-from fundamental assumptions of various modeling components (e.g., fixed boundaries in atmospheric and ocean GCMs vs evolving boundaries in the ice sheet models) to disparity of the characteristic temporal and spatial time scales. To make progress, a closer interaction between the communities involved and the model developers needs to be established. Given the multitude of disciplines involved, the emergence of a new generation of scientists with an interdisciplinary background would greatly benefit this problem.

- Model testing, analysis, and intercomparison. The hierarchy of modeling approaches described above is required as a quantitative basis for model verification and validation, and identification of systematic biases. The hierarchy covers small-scale process modeling for the purpose of developing parameterizations for inclusion into large-scale Earth system models, to model-data synthesis frameworks to integrate available observations with models, both small scale and global scale.

- Observing system design and evaluation. Observing system studies are required to assess which processes have the strongest impact on constraining ice mass loss, and where, with what accuracy, and at which frequency these should be sampled. In conjunction with synthesis/data assimilation systems, this can be achieved through observing system simulation experiments (OSSEs). The large scale-small scale and observationmodel feedback loops should ultimately point to more targeted field campaigns to close the major gaps in linking process understanding and climate model representation. The synthesis/data assimilation systems also provide suitable frameworks for quantifying uncertainties in the link between climate forcings and glacier responses.

CONCLUSIONS. This document provides clear evidence that understanding of ice sheet-ocean interactions is a fundamental requirement for providing realistic projections of Greenland's behavior in coming decades to centuries, which, in turn, are key to reducing uncertainties in sea level rise projections and freshwater discharge into the climatesensitive North Atlantic and Arctic Oceans. Critical aspects of Greenland's coupled ice sheet-ocean system are identified, and a research agenda is outlined that will yield fundamental insights into how the ice sheet and ocean interact, their role in Earth's climate system, their regional and global effects, and probable trajectories of future changes.

Key elements of the research agenda are focused process studies, sustained observational efforts at key sites, and inclusion of the relevant dynamics in Earth system models. Interdisciplinary and multiagency efforts, as well as international cooperation, are 
crucial to making progress on this novel and complex problem. Integration of this new knowledge into a comprehensive picture of the coupled North AtlanticArctic-Greenland system will be a significant step toward fulfilling the goal of credibly projecting sea level rise over the coming decades and century.

ACKNOWLEDGMENTS. This is a contribution to the activity of the U.S. CLIVAR Working Group on Greenland Ice Sheet-Ocean Interactions (GRISO). Mike Patterson is thanked for his engagement and guidance. The idea for establishment of such a working group originated during the Advanced Climate Dynamics Course (ACDC) 2010 on Ice Sheet-Ocean Interactions at the MIT-Fablab in Lyngen, Norway (see http://onlinelibrary.wiley.com /doi/10.1029/2010EO450006/abstract), with the Norwegian Centre for International Cooperation in Education (SiU) as its main sponsor. We thank three anonymous reviewers for their comments.

\section{REFERENCES}

Allen, C., 2010: IceBridge MCoRDS L2 ice thickness: Greenland 2010 MCoRDS 12 ice thickness data. NASA Distributed Active Archive Center at the National Snow and Ice Data Center, Boulder, CO, digital media. [Available online at http://nsidc.org /data/irmcr2.html.]

Amundson, J. M., M. Fahnestock, M. Truffer, J. Brown, M. P. Lüthi, and R. J. Motyka, 2010: Ice mélange dynamics and implications for terminus stability, Jakobshavn Isbræ, Greenland. J. Geophys. Res., 115, F01005, doi:10.1029/2009JF001405.

Andersen, M. L., M. Nettles, P. Elosegui, T. B. Larsen, G. S. Hamilton, and L. A. Stearns., 2011: Quantitative estimates of velocity sensitivity to surface melt variations at a large Greenland outlet glacier. J. Glaciol., 57, 609-620.

Andresen, C. S., and Coauthors, 2012: Rapid response of Helheim Glacier in Greenland to climate variability over the past century. Nat. Geosci., 5, 37-41.

Bamber, J., M. van den Broeke, J. Ettema, J. Lenaerts, and E. Rignot, 2012: Recent large increases in freshwater fluxes from Greenland into the North Atlantic. Geophys. Res. Lett., 39, L19501, doi:10.1029/2012GL052552.

Bartholomew, I., P. Nienow, A. Sole, D. Mair, T. Cowton, and M. A. King, 2012: Short-term variability in Greenland Ice Sheet motion forced by timevarying meltwater drainage: Implications for the relationship between subglacial drainage system behavior and ice velocity. J. Geophys. Res., 117, F03002, doi:10.1029/2011JF002220.
Bersch, M., I. Yashayaev, and K. P. Koltermann, 2007: Recent changes of the thermohaline circulation in the subpolar North Atlantic. Ocean Dyn., 57, 223-235.

Bevis, M., and Coauthors, 2012: Bedrock displacements in Greenland manifest ice mass variations, climate cycles and climate change. Proc. Natl. Acad. Sci. USA, 109, 11 944-11 948, doi:10.1073 /pnas.1204664109.

Bindschadler, R. A., P. U. Clark, and D. Holland, Eds., 2011: A research program for projecting future sea-level rise from land-ice loss. A Science and Implementation Plan to the U.S. National Science Foundation, NSF, 37 pp. [Available online at www .nsf.gov/od/opp/usap_special_review /science_review/science_docs/nsf_sea-level_rpt.pdf.] Borreguero, L. H., R. Mottram, and I. Cvijanovic, 2010: Discussing progress in understanding ice sheet-ocean interactions: Advanced climate dynamics course 2010: Ice sheet-ocean interactions. Eos, Trans. Amer. Geophys. Union, 91, 419, doi:10.1029/2010EO450006.

Cappelen, J., Ed., 2010: DMI monthly climate data collection 1768-2009, Denmark, the Faroe Islands and Greenland. Dansk Meterologisk Institut Tech. Rep. 10-05, 52 pp. [Available online at www.dmi.dk/dmi /tr10-05.pdf.]

Cazenave, A., and W. Llovel, 2010: Contemporary sea level rise. Annu. Rev. Mar. Sci., 2, 145-173.

Christoffersen, P., R. I. Mugford, K. J. Heywood, I. Joughin, J. A. Dowdeswell, J. P. M. Syvitski, A. Luckman, and T. J. Benham, 2011: Warming of waters in an East Greenland fjord prior to glacier retreat: Mechanisms and connection to large-scale atmospheric conditions. Cryosphere, 5, 701-714.

Church, J. A. and N. J. White, 2011: Sea-level rise from the late 19th to the early 21st Century. Surv. Geophys., 32, 585-602, doi:10.1007/s10712-011-9119-1.

Colgan, W., K. Steffen, W. S. McLamb, W. Abdalati, H. Rajaram, R. Motyka, T. Phillips, and R. Anderson, 2011: An increase in crevasse extent, west Greenland: Hydrologic implications. Geophys. Res. Lett., 38, L18502, doi:10.1029/2011GL048491.

Davini, P., C. Cagnazzo, R. Neale, and J. Tribbia, 2012: Coupling between Greenland blocking and the North Atlantic Oscillation pattern. Geophys. Res. Lett., 39, L14701, doi:10.1029/2012GL052315.

Falkner, K. K., and Coauthors, 2011: Context for the recent massive Petermann Glacier calving event. Eos, Trans. Amer. Geophys. Union, 92, 117-124.

Favier, L., O. Gagliardini, G. Durand, and T. Zwinger, 2012: A three-dimensional full Stokes model of the grounding line dynamics: Effect of a pinning 
point beneath the ice shelf. Cryosphere, 6, 101-112, doi:10.5194/tc-6-101-2012.

Fettweis, X., M. Tedesco, M. van den Broeke, and J. Ettema, 2011: Melting trends over the Greenland Ice Sheet (1958-2009) from spaceborne microwave data and regional climate models. Cryosphere, 5, 359-375, doi:10.5194/tc-5-359-2011.

Haine, T. W. N., S. Zhang, G. W. K. Moore, and I. A. Renfrew, 2009: On the impact of high-resolution, high-frequency meterological forcing on Denmark Strait ocean circulation. Quart. J. Roy. Meteor. Soc., 135, 2067-2085, doi:10.1002/qj.505.

Hall, D. K., R. S. Williams Jr., S. B. Luthcke, and N. E. Digirolamo, 2008: Greenland Ice Sheet surface temperature, melt and mass loss: 2000-2006. J. Glaciol., 54, 81-93, doi:10.3189/002214308784409170.

Hanna, E., J. Cappelen, X. Fettweis, P. Huybrechts, A. Luckman, and M. H. Ribergaard, 2009: Hydrologic response of the Greenland Ice Sheet: The role of oceanographic warming. Hydrol. Proc., 23, 7-30, doi:10.1002/hyp.7090.

Hellmer, H. H., and D. J. Olbers, 1989: A two-dimensional model of the thermohaline circulation under an ice shelf. Antarct. Sci., 1, 325-336.

Hoffman, M. J., G. A. Catania, T. A. Neumann, L. C. Andrews, and J. A. Rumrill, 2011: Links between acceleration, melting, and supraglacial lake drainage of the western Greenland Ice Sheet. J. Geophys. Res., 116, F04035, doi:10.1029/2010JF001934.

Holland, D. M., and A. Jenkins, 1999: Modeling thermodynamic ice-ocean interaction at the base of an ice shelf. J. Phys. Oceanogr., 29, 1787-1800.

—, R. H. Thomas, B. de Young, M. H. Ribergaard, and B. Lyberth, 2008: Acceleration of Jakobshavn Isbræ triggered by warm subsurface ocean waters. Nat. Geosci., 1, 659-664.

Howat, I. M., I. Joughin, and T. A. Scambos, 2007: Rapid changes in ice discharge from Greenland outlet glaciers. Science, 315, 1559-1561.

— J. E. Box, Y. Ahn, A. Herrington, and E. M. McFadden, 2010: Seasonal variablity in the dynamics of marine-terminating outlet glaciers in Greenland. J. Glaciol., 56, 601-613.

- , Y. Ahn, I. Joughin, M. R. van den Broeke, J. T. M. Lenaerts, and B. Smith, 2011: Mass balance of Greenland's three largest outlet glaciers, 2000-2010. Geophys. Res. Lett., 38, L12501, doi:10.1029/2011GL047565.

Hughes, T., 1986: The Jacobshavn effect. Geophys. Res. Lett., 13, 46-48.

Jenkins, A., 1991: A one-dimensional model of ice shelf-ocean interaction. J. Geophys. Res., 96 (C11), 20671-20677.
—, 2011: Convection-driven melting near the grounding lines of ice shelves and tidewater glaciers. J. Phys. Oceanogr., 41, 2279-2294.

—, K. W. Nicholls, and H. F. J. Corr, 2010: Observation and parameterization of ablation at the base of Ronne Ice Shelf, Antarctica. J. Phys. Oceanogr., 40, 2298-2312.

Jiang, Y., T. H. Dixon, and S. Wdowinski, 2010: Accelerating uplift in the North Atlantic region as an indicator of ice loss. Nat. Geosci., 3, 404-407, doi:10.1038/ngeo845.

Johnson, H. L., A. Münchow, K. K. Falkner, and H. Melling, 2011: Ocean circulation and properties in Petermann Fjord, Greenland. J. Geophys. Res., 116, C01003, doi:10.1029/2010JC006519.

Joughin, I., and R. B. Alley, 2011: Stability of the West Antarctic ice sheet in a warming world. Nat. Geosci., 4, 506-513.

—, M. Fahnestock, D. MacAyeal, J. L. Bamber, and P. Gogineni, 2001: Observation and analysis of ice flow in the largest Greenland ice stream. J. Geophys. Res., 106 (D24), 34021-34034.

—, W. Abdalati, and M. Fahnestock, 2004: Large fluctuations in speed on Greenland's Jakobshavn Isbræ Glacier. Nature, 432, 608-610, doi:10.1038/ nature 03130 .

—, S. B. Das, M. A. King, B. E. Smith, I. M. Howat, and T. Moon, 2008: Seasonal speedup along the western flank of the Greenland Ice Sheet. Science, 320, 781-783.

—, B. E. Smith, I. M. Howat, T. Scambos, and T. Moon, 2010: Greenland flow variability from ice-sheet-wide velocity mapping. J. Glaciol., 56, 416-430.

$-, \ldots,-$, D. Floricioiu, R. B. Alley, M. Truffer, and M. Fahnestock, 2012: Seasonal to decadal scale variations in the surface velocity of Jakobshavn Isbrae, Greenland: Observation and model-based analysis. J. Geophys. Res., 117, F02030, doi:10.1029/2011JF002110. Khan, S. A., J. Wahr, M. Bevis, I. Velicogna, and E. Kendrick, 2010: Spread of ice mass loss into northwest Greenland observed by GRACE and GPS. Geophys. Res. Lett., 37, L06501, doi:10.1029/2010GL042460.

Klein, T., and G. Heinemann, 2002: Interaction of katabatic winds and mesocyclones near the eastern coast of Greenland. Meteor. Appl., 9, 407-422.

Larour, E., H. Seroussi, M. Morlighem, and E. Rignot, 2012: Continental scale, high order, high spatial resolution, ice sheet modeling using the Ice Sheet System Model (ISSM). J. Geophys. Res., 117, F01022, doi:10.1029/2011JF002140.

Lemke, P., and Coauthors, 2007: Observations: Changes in snow, ice and frozen ground. Climate Change 2007: The Physical Science Basis, S. Solomon et al., Eds, Cambridge University Press, 337-383. 
Little, C., and Coauthors, 2007: Toward a new generation of ice sheet models. Eos, Trans. Amer. Geophys. Union, 88, 578-579.

Lloyd, J. M., M. Moros, K. Perner, R. Telford, A. Kuijpers, E. Jansen, and D. A. McCarthy, 2011: A 100 year record of ocean temperature control on the stability of Jakobshavn Isbrae, west Greenland. Geology, 39, 867-870, doi:10.1130/G32076.1.

Luckman, A., T. Murray, R. de Lange, and E. Hanna, 2006: Rapid and synchronous ice-dynamic changes in East Greenland. Geophys. Res. Lett., 33, L03503, doi:10.1029/2005GL025428.

MacAyeal, D. R., J. Freed-Brown, W. W. Zhang, and J. M. Amundson, 2012: The influence of ice mélange on fjord seiches. Ann. Glaciol., 53, 45-49.

Manabe, S., and R. J. Stouffer, 1988: Two stable equilibria of a coupled ocean-atmosphere model. J. Climate, 1, 841-866. [Available online at http://dx.doi .org/10.1175/1520-0442(1988)001<0841:TSEOAC> 2.0.CO;2.]

Mayer, C., N. Reeh, F. Jung-Rothenhäusler, P. Huybrechts, and H. Oerter, 2000: The subglacial cavity and implied dynamics under Nioghalvfjerdsfjorden Glacier, NE-Greenland. Geophys. Res. Lett., 27, 2289-2292, doi:10.1029/2000GL011514.

Meier, M. F., M. B. Dyurgerov, U. K. Rick, S. O’Neel, W. T. Pfeffer, R. S. Anderson, S. P. Anderson, and A. F. Glazovsky, 2007: Glaciers dominate eustatic sea-level rise in the 21st century. Science, 317, 1064-1067, doi:10.1126/science.1143906.

Mix, A. C., R. Samelson, and L. Padman, Eds., 2012: Interdisciplinary approaches to understanding atmosphere/ocean/ice shelf/ice sheet interactions. NSF Workshop Rep., 31 pp.

Moon, T., I. Joughin, B. Smith, and I. Howat, 2012: 21st-century evolution of Greenland outlet glacier velocities. Science, 336, 576-578.

Moore, G. W. K., and I. A. Renfrew, 2005: Tip jets and barrier winds: A QuickSCAT climatology of high wind speed events around Greenland. J. Climate, 18, 3713-3725.

Mortensen, J., K. Lennert, J. Bendtsen, and S. Rysgaard, 2011: Heat sources for glacial melt in a subArctic fjord (Godthåbsfjord) in contact with the Greenland Ice Sheet. J. Geophys. Res., 116, C01013, doi:10.1029/2010JC006528.

Motyka, R. J., M. Truffer, M. Fahnestock, J. Mortenson, S. Rysgaard, and I. Howat, 2011: Submarine melting of the 1985 Jakobshavn Isbræ floating ice tongue and the triggering of the current retreat. J. Geophys. Res., 116, F01007, doi:10.1029/2009JF001632.

Murray, T., and Coauthors, 2010: Ocean regulation hypothesis for glacier dynamics in southeast Greenland and implications for ice sheet mass changes. J. Geophys. Res., 115, F03026, doi:10.1029/2009JF001522.

Nerem, R. S., and J. Wahr, 2011: Recent changes in the Earth's oblateness driven by Greenland and Antarctic ice mass loss. Geophys. Res. Lett., 38, L13501, doi:10.1029/2011GL047879.

Nick, F. M., A. Vieli, I. M. Howat, and I. Joughin, 2009: Large-scale changes in Greenland outlet glacier dynamics triggered at the terminus. Nat. Geosci., 2, 110-114.

— , and Coauthors, 2012: The response of Petermann Glacier, Greenland, to large calving events, and its future stability in the context of atmospheric and oceanic warming. J. Glaciol., 58, 229-239, doi:10.3189/2012JoG11J242.

Pfeffer, W. T., 2007: A simple mechanism for irreversible tidewater glacier retreat. J. Geophys. Res., 112, F03S25, doi:10.1029/2006JF000590.

—, J. T. Harper, and S. O’Neel, 2008: Kinematic constraints on glacier contributions to 21st-century sea-level rise. Science, 321, 1340-1343.

Phillips, T., H. Rajaram, and K. Steffen, 2010: Cryohydrologic warming: A potential mechanism for rapid thermal response of ice sheets. Geophys. Res. Lett., 37, L20503, doi:10.1029/2010GL044397.

Polyakov, I. V., and Coauthors, 2004: Variability of the intermediate Atlantic water of the Arctic Ocean over the last 100 years. J. Climate, 17, 4485-4497.

Post, A., S. O’Neel, R. J. Motyka, and G. Streveler, 2011: A complex relationship between calving glaciers and climate. Eos, Trans. Amer. Geophys. Union, 82, 305-312.

Price, S. F., H. Conway, E. D. Waddington, and R. A. Bindschadler, 2008: Model investigations of inland migration of fast-flowing outlet glaciers and ice streams. J. Glaciol., 54, 49-60.

—, A. J. Payne, I. M. Howat, and B. E. Smith, 2011: Committed sea-level rise for the next century from Greenland Ice Sheet dynamics during the past decade. Proc. Natl. Acad. Sci. USA, 108, 8978-8983.

Pritchard, H. D., R. J. Arthern, D. G. Vaughan, and L. A. Edwards, 2009: Extensive dynamic thinning on the margins of the Greenland and Antarctic ice sheets. Nature, 461, 971-975.

Rahmstorf, S., 2007: A semi-empirical approach to projecting future sea-level rise. Science, 315, 368-370.

Reeh, N., H. H. Thomsen, A. K. Higgins, and A. Weidick, 2001: Sea ice and the stability of north and northeast Greenland floating glaciers. Ann. Glaciol., 33, 474-480.

Rignot, E., and P. Kanagaratnam, 2006: Changes in the velocity structure of the Greenland Ice Sheet. Science, 311, 986-990. 
—_ and K. Steffen, 2008: Channelized bottom melting and stability of floating ice shelves. Geophys. Res. Lett., 35, L02503, doi:10.1029/2007gl031765.

_-, M. Koppes, and I. Velicogna, 2010: Rapid submarine melting of the calving faces of west Greenland glaciers. Nat. Geosci., 3, 187-191.

Schauer, U., A. Beszczynska-Möller, W. Walczowski, E. Fahrbach, J. Piechura, and E. Hansen, 2008: Variation of measured heat flow through the Fram Strait between 1997 and 2006. Arctic-Subarctic Ocean Fluxes: Defining the Role of the Northern Seas in Climate, B. Dickson, J. Meincke, and P. Rhines, Eds., Springer Verlag, 65-85.

Schoof, C., 2010: Ice-sheet acceleration driven by melt supply variability. Nature, 468, 803-806.

Sciascia, R., F. Straneo, C. Cenedese, and P. Heimbach, 2013: Seasonal variability of submarine melt rate and circulation in an East Greenland fjord. J. Geophys. Res., 118, 1-15, doi:10.1002/jgrc.20142.

Seddik, H., R. Greve, T. Zwinger, F. Gillet-Chaulet, and O. Gagliardini, 2012: Simulations of the Greenland Ice Sheet 100 years into the future with the full Stokes model Elmer/Ice. J. Glaciol., 58, 427-440, doi:10.3189/2012JoG11J177.

Seroussi, H., M. Morlighem, E. Rignot, E. Larour, D. Aubry, H. Ben Dhia, and S. S. Kristensen, 2011: Ice flux divergence anomalies on 79North Glacier, Greenland. Geophys. Res. Lett., 38, L09501, doi:10.1029/2011GL047338.

Shepherd, A., and Coauthors, 2012: A reconciled estimate of ice-sheet mass balance. Science, 338, 1183-1189.

Sohn, H. G., K. C. Jezek, and C. J. van der Veen, 1998: Jakobshavn Glacier, west Greenland: 30 years of spaceborne observations. Geophys. Res. Lett., 25, 2699-2702.

Sole, A., T. Payne, J. Bamber, P. Nienow, and W. Krabill, 2008: Testing hypotheses of the cause of peripheral thinning of the Greenland Ice Sheet: Is landterminating ice thinning at anomalously high rates? Cryosphere, 2, 205-218.

Stearns, L. A., and G. S. Hamilton, 2007: Rapid volume loss from two east Greenland outlet glaciers quantified using repeat stereo satellite imagery. Geophys. Res. Lett., 34, L05503, doi:10.1029/2006GL028,982.

Straneo, F., G. S. Hamilton, D. A. Sutherland, L. A. Stearns, F. Davidson, M. O. Hammill, G. B. Stenson, and A. Rosing-Asvid, 2010: Rapid circulation of warm subtropical waters in a major, East Greenland glacial fjord. Nat. Geosci., 3, 182-186.

—, R. G. Curry, D.A. Sutherland, G. S. Hamilton, C. Cenedese, K. Väge, and L.A. Stearns, 2011: Impact of fjord dynamics and glacial runoff on the circulation near Helheim Glacier. Nat. Geosci., 4, 332-327, doi:10.1038/ngeo1109.

—, D. Sutherland, D. Holland, C. Gladish, G. Hamilton, H. Johnson, E. Rignot, Y. Xu, and M. Koppes, 2012: Characteristics of ocean waters reaching Greenland's glaciers. Ann. Glaciol., 53, 202-210.

Sundal, A. V., A. Shepherd, P. Nienow, E. Hanna, S. Palmer, and P. Huybrechts, 2011: Melt-induced speed-up of Greenland Ice Sheet offset by efficient subglacial drainage. Nature, 469, 521-524.

Sutherland, D. A., and R. S. Pickart, 2008: The East Greenland Coastal Current: Structure, variability, and forcing. Prog. Oceanogr., 78, 58-77.

— , and F. Straneo, 2012: Estimating ocean heat transports and submarine melt rates in Sermilik Fjord, Greenland, using lowered ADCP velocity profiles. Ann. Glaciol., 53, 50-58.

Tedesco, M., X. Fettweis, M. R. van den Broeke, R. S. W. van de Wal, C. J. P. P. Smeets, W. J. van de Berg, M. C. Serreze, and J. E. Box, 2011: The role of albedo and accumulation in the 2010 melting record in Greenland. Environ. Res. Lett., 6, 014005 , doi:10.1088/1748-9326/6/1/014005.

Thomas, R. H., 2004: Force-perturbation analysis of recent thinning and acceleration of Jakobshavn Isbrae, Greenland. J. Glaciol., 50, 57-66.

Truffer, M., and K. A. Echelmeyer, 2003: Of isbrae and ice streams. Ann. Glaciol., 36, 66-72.

U.S. CLIVAR Project Office, 2012a: Fourth annual progress report for a SOST near-term priority assessing meridional overturning circulation variability: Implications for rapid climate change, U.S. CLIVAR Office Rep. 2012-1, 100 pp.

_ $2012 \mathrm{~b}$ : Understanding the dynamic response of Greenland's marine terminating glaciers to oceanic and atmospheric forcing: A white paper by the U.S. CLIVAR Working Group on Greenland Ice SheetOcean Interactions (GRISO), U.S. CLIVAR Project Office Rep. 2012-2, 22 pp.

van den Broeke, M., J. Bamber, J. Ettema, E. Rignot, E. Schrama, W. Jan van de Berg, W.E. van Meijgaard, I. Velicogna, and B. Wouters, 2009: Partitioning recent Greenland mass loss. Science, 326, 984-986, doi:10.1126/science.1178176.

van der Veen C., J. C. Plummer, and L. A. Sterns, 2011: Controls on the recent speed-up of Jakobshavn Isbrae, west Greenland. J. Glaciol., 57, 770-782.

Vermeer, M., and S. Rahmstorf, 2009: Global sea level linked to global temperature. Proc. Natl. Acad. Sci. USA, 106, 21 527-21 532, doi:10.1073/ pnas.0907765106.

Vieli, A., and F. M. Nick, 2011: Understanding and modelling rapid dynamical changes of tidewater outlet 
glaciers: Issues and implications. Surv. Geophys., 32, 437-458, doi:10.1007/s10712-011-9132-4.

Walter, J., J. E. Box, S. Tulaszyk, E. Brodsky, I. M. Howat, Y. Ahn, and A. Brown, 2012: Oceanic mechanical forcing of the dynamics of a marine-terminating Greenland glacier by ice mélange removal and ocean tides. Ann. Glaciol., 53, 181-192.

Weijer, W., M. E. Maltrud, M. W. Hecht, H. A. Dijkstra, and M. A. Kliphuis, 2012: Response of the Atlantic Ocean circulation to Greenland Ice Sheet melting in a strongly-eddying ocean model. Geophys. Res. Lett., 39, L09606, doi:10.1029/2012GL051611.

Wunsch, C., P. Heimbach, R. Ponte, I. Fukumori, and the ECCO-GODAE Consortium members, 2009: The global general circulation of the ocean estimated by the ECCO-Consortium. Oceanography, 22, 88-103.

Xu, Y., E. Rignot, D. Menemenlis, and M. Koppes, 2012: Numerical experiments on subaqueous melting of Greenland tidewater glaciers in response to ocean warming and enhanced subglacial discharge. Ann. Glaciol., 53, 229-234.

Yin, J., J. T. Overpeck, S. M. Griffies, A. Hu, J. L. Russell, and R. J. Stouffer, 2011: Different magnitudes of projected subsurface ocean warming around Greenland and Antarctica. Nat. Geosci., 4, 524-528, doi:10.1038/ ngeo1189.

Zweng, M. M., and A. Münchow, 2006: Warming and freshening of Baffin Bay, 1916-2003. J. Geophys. Res., 111, C07016, doi:10.1029/2005JC003093. 